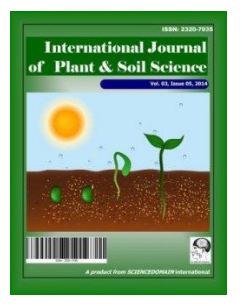

\title{
Assessment of Land Suitability and Water Requirements for Different Crops in Dakhla Oasis, Western Desert, Egypt
}

\author{
Mohamed E. Fadl ${ }^{1}$ and Ahmed S. Abuzaid ${ }^{2}$ \\ ${ }^{1}$ National Authority for Remote Sensing and Space Sciences (NARSS), Cairo, Egypt. \\ ${ }^{2}$ Department of Soil and Water, Faculty of Agriculture, Benha University, Egypt.
}

\begin{abstract}
Authors' contributions
This work was carried out in collaboration between both authors. Author MEF performed remote sensing and GIS works. Author ASA wrote the protocol and wrote the first draft of the manuscript. Both authors performed field and laboratory analysis, managing the analyses and read and approved the manuscript.

Article Information

DOI: $10.9734 / / J P S S / 2017 / 33835$

Editor(s):

(1) Nasima Junejo, Department of Forest Production, Faculty of Forestry, Universiti Putra Malaysia, Selangor, Malaysia. Reviewers:

(1) B. P. Bhaskar, National Bureau of Soil Survey and Land Utilisation Planning, India (2) Işın Onur, Akdeniz University, Turkey. Complete Peer review History: http://www.sciencedomain.org/review-history/19577
\end{abstract}

Original Research Article

Received $30^{\text {th }}$ April 2017

Accepted $27^{\text {th }}$ May 2017

Published $16^{\text {th }}$ June 2017

\begin{abstract}
Land reclamation projects in Egypt have been directed towards the Western Desert; however, such expansion requires devoting land and water resources to the optimum use. Hence, the current work aimed at assessing land suitability and water requirements for various crops in an area located west of Dakhla Oasis. The geomorphic features were identified after the processing of Landsat 8.0 satellite image and Digital elevation model (DEM) verified by field and ground studies. Samples of thirty-one soil profiles and eleven water wells were collected and analyzed. Land suitability was assessed using MicroLEIS software with an Almagra model. The main geomorphic units are plateau, pediplain, depression and sand sheets. About $97 \%$ of the soils are suitable (high, moderate and marginal) for maize, sunflower, soya bean, wheat, sugar beet, cotton, watermelon, alfalfa, potato, peach, citrus, and olive. Water requirements for each crop were calculated using FAO-Cropwat model as 816.33, 795.98, 1003.83, 550.78, 865.13, 1150.83, 797.87, 2113.47, $397.37,1577.86,1503.92$ and $1163.96 \mathrm{~mm}$, respectively. The area has water resources with high quality for irrigation, and thus it is considered promising for agricultural expansion
\end{abstract}


Keywords: Land suitability; almagra model; dakhla oasis; western desert; GIS; remote sensing.

\section{INTRODUCTION}

Overpopulation, limited arable land, and water scarcity are the main problems facing Egypt [1]. Therefore, increasing the area of cultivated land is vital [2]. This is achieved via reclaiming more lands, particularly in the desert which occupy more than $96 \%$ of the total area of Egypt [3], but with limited scope for agricultural expansion in the Nile Valley and Delta [4]. Expansion of arable lands increases the national production and supports different developmental projects [5].

Major agricultural expansion, industry and civil activities are planned in the Western Desert [6,7], which covers $66.7 \%$ of the total area of Egypt having seven depressions; Siwa, Qattara, Fayum, Bahariya, Farafra, Dakhla, and Kharga, where the freshwater exist in the Oasis [8]. The Nubian Sandstone Aquifer (NSSA), the major ground water aquifer in Egypt, is in this desert [9]. Dakhla Oasis is situated in the heart of the Western Desert. It has high fertile lands and is the main Oasis which supports high population [10]. This is due to the large amount of groundwater presented in this locality, where the thickness of the NSSA ranges between 600 and $900 \mathrm{~m}$. Therefore, this area should take a priority in the sustainable development project of southern Egypt [11]. The two main parameters should be under detailed study are soil suitability and water availability for crops [7]. Unless there are reliable information concerning land and water resources, agricultural expansion will not be positive [12].

Land suitability assessment plays an important role in planning and managing sustainable land use [13]. It provides useful information and helps in optimizing agricultural land use [14]. This is due to its impacts on appropriate land use and reasonable urban layout[15]. Remote sensing (RS) provides a cost-effective and quick technique to collect accurate data. Geographic Information System (GIS) can manipulate, analyze, and display the data, giving better results for RS image classification. Thus, a combined use becomes more realistic [16]. They are applied to an area for developing a strategy optimally fitting the local resources and potential productivity [17]. One of the most beneficial applications of GIS in planning land recourses is preparing land use maps [18]. Hence, the current work aimed at integrating $\mathrm{RS}$ and GIS for mapping agricultural land suitability for some soils located in the West of Dakhla Oasis, Western Desert, Egypt. Crop water requirements for each of the selected crops were also considered for sustainable land used planning.

\section{MATERIALS AND METHODS}

\subsection{The Area of Study}

The studied area covers $555.27 \mathrm{~km}^{2}$ between longitudes $28^{\circ} 25^{\prime} 13.284^{\prime \prime}$ to $28^{\circ} 39^{\prime} 48.753^{\prime \prime} \mathrm{E}$ and latitude $25^{\circ} 43^{\prime} 49.983^{\prime \prime}$ to $25^{\circ} 56^{\prime} 14.844^{\prime \prime} \mathrm{N}$ (Fig. 1). Brookes [19] stated that the area is underlain by a sequence of sedimentary rocks of Cenomanian to Palaeocene eras. Dakhla shales and Quseir formation (variegated shale, mudstone, siltstone and flaggy sandstone) is forming most of the lithological units, while a small part in the area is developed on Duwi formation (mudstones, silicified limestones, and phosphorites). According to Egyptian Meteorological Authority EMA [20], the area receives very low annual rainfall of $0.5 \mathrm{~mm}$. The mean annual temperature is $23.6^{\circ} \mathrm{C}$ and the maximum value reaches $40.3^{\circ} \mathrm{C}$ during July, while the minimum one decreases to $5.5^{\circ} \mathrm{C}$ during January. According to Soil Survey Staff [21], the soil temperature regime is Hyperthermic and the soil moisture regime is Torric.

\subsection{Digital Image Processing}

Processing of a Landsat-8 operational land imager (OLI) satellite image (path 177, row 42) with a spatial resolution of $30 \mathrm{~m}$ dated to 27-032016, was executed using ENVI 5.1 Software [22]. Data were calibrated to radiance depending on image type, acquisition date, and time. The image was stretched using linear $2 \%$, smoothly filtered, and their histograms were matched according to Lillesand et al. [23]. The image was atmospherically corrected using FLAASH module. Fusion methodology [24] was applied to produce an image covering the area of study.

\subsection{Map Creation}

A digital elevation model (DEM) of $30 \mathrm{~m}$ pixel size resolution, acquired from the Shuttle Radar Topographic Mission (SRTM) images on 27-032016, was the source for elevation heights of the study area (Fig. 2). The DEM was presented in 3D mode and was then overlaid by the OLI image to generate a 3D image [25], which was consequently used along with the ground truth 


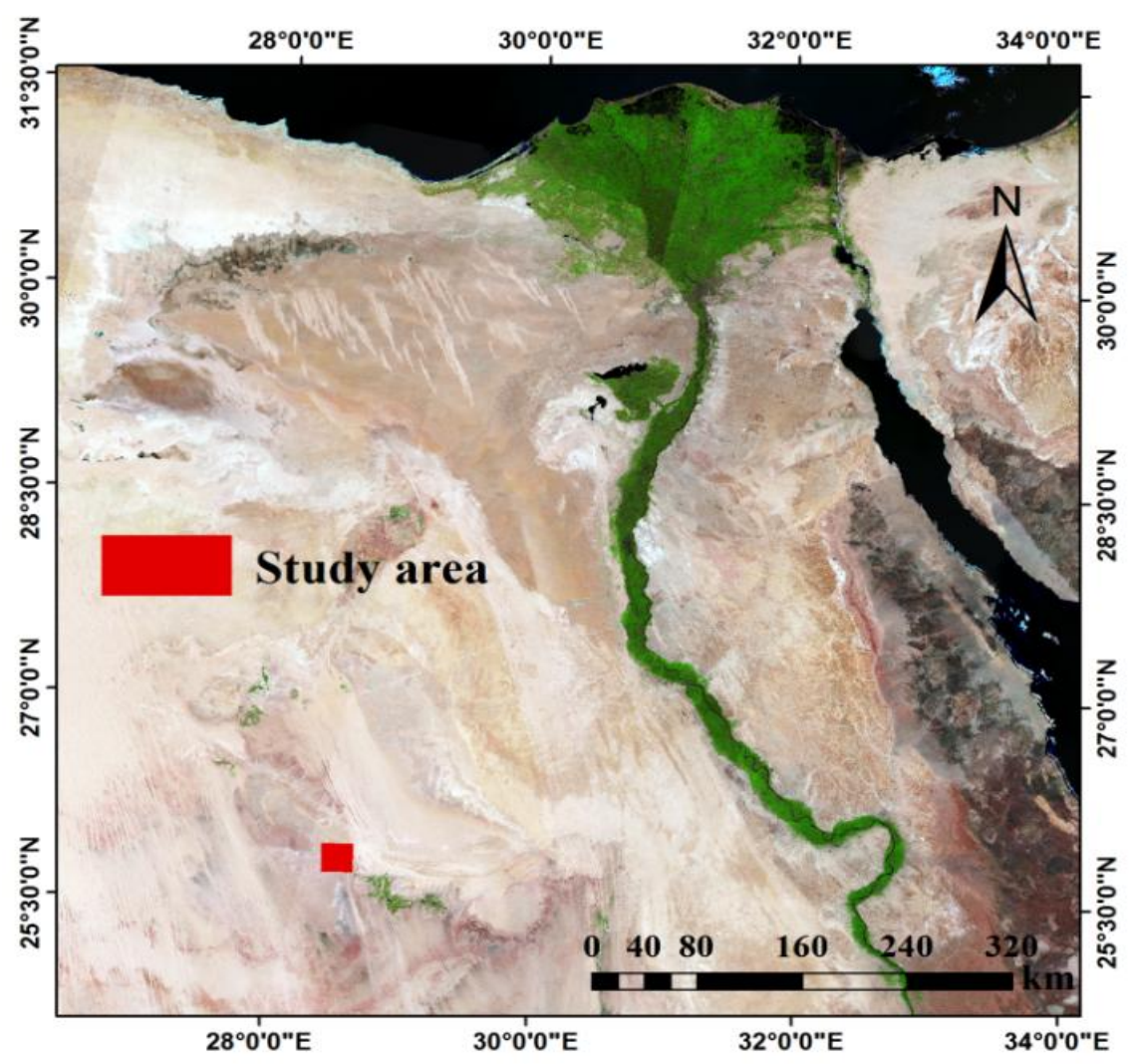

Fig. 1. Location map of the studied area

data to extract the different landforms of the area. The geomorphic units were described according to Zinck and Valenzuela [26]. The units were imported into a Geodatabase as a base map to generate and display various maps using ArcGIS 10.2.2 software [27].

\subsection{Field Work and Laboratory Analysis}

Field and ground studies were done to identify the reality of digital image interpretation, obtain more details of the soil patterns, landforms and characteristic of the landscape. Thirty-one soil profiles were georeferenced using GPS and then dug (Fig. 3). The profiles were described according to the FAO guidelines [28]. Soil samples (151 sample) were collected from the profiles for laboratory analyses using the standard methods as outlined by Soil Survey Staff [29]. Soils were classified as per Keys to soil taxonomy [21]. Irrigation water samples were collected from eleven drilled water wells and subsequently analyzed. The depth of the drilled wells ranged in depth from $436 \mathrm{~m}$ to $1.08 \mathrm{~km}$ below the soil surface. Water quality for agriculture was evaluated according to the FAO guidelines for interpretations for irrigation [30].

\subsection{Land Suitability Evaluation}

The Microcomputer Land Evaluation Information System (MicroLEIS) [31] with an Almagra model (Agricultural Soil Suitability) was used for land suitability appraisal. This automatized application of soil suitability method was used to evaluate agricultural crop suitability through matching land and soil characteristics with growth requirements for the selected crops (Fig. 4). In the current study, twelve traditional Mediterranean crops; wheat, maize, watermelon, potato, soybean, cotton, sunflower, sugar beet, alfalfa, peach, citrus, and olive were selected to be evaluated. The criteria used for evaluating land suitability were useful depth $(\mathrm{cm})$, stoniness $(\%)$, texture, drainage, carbonate content (\%), salinity (dS $\mathrm{m}^{-}$ ${ }^{1}$ ), sodium saturation (\%) and soil profile development (Fig. 5). Weighted average value for each soil property was calculated by multiplying the parameter value of each horizon by horizon thickness and divided by the total profile depth. The weighted values were the input 
values for Almagra model in order to run suitability evaluation for the selected crops. Land suitability classes were calculated following a semi-quantitative procedure and the results were shown by the computer. The definitions of suitability classes, soil factors and the intensity of limitations are shown in Table 1.

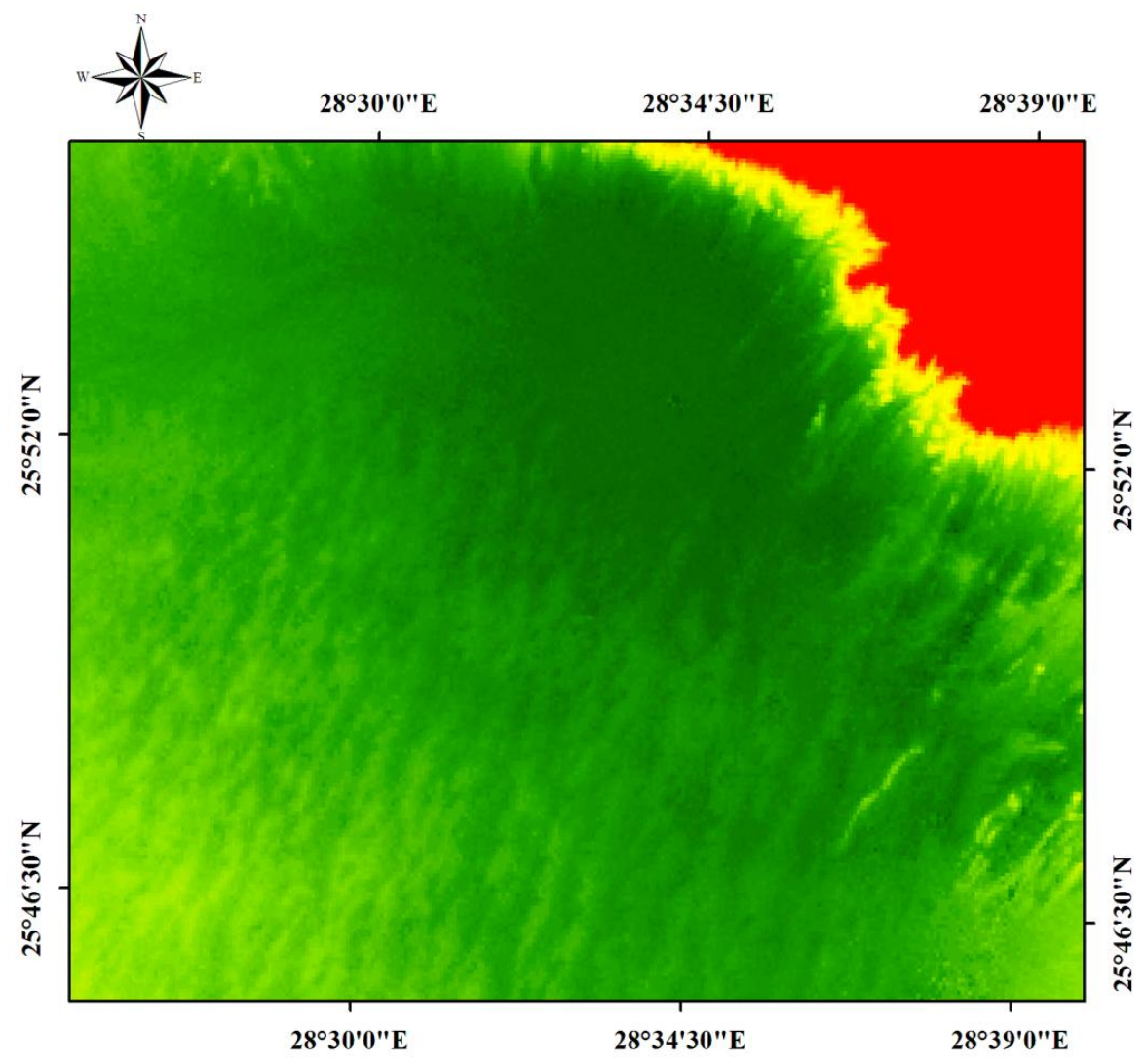

Surface elevation, m. a. s. $l$.
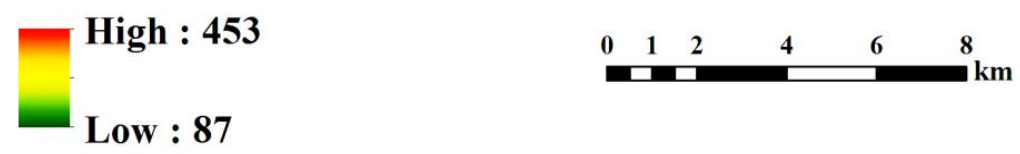

Fig. 2. Digital elevation model (DEM) of the studied area

Table 1. The suitability classes, limitations and soil factors used in Almagra model

\begin{tabular}{llllll}
\hline \multicolumn{2}{c}{ Suitability classes } & \multicolumn{2}{c}{ Limitation } & & Soil factor \\
\hline Symbol & Definition & Symbol & Definition & Symbol & Definition \\
\hline S1 & Optimum suitable & 1 & None & $\mathrm{p}$ & Useful depth \\
S2 & High suitable & 2 & Slight & $\mathrm{t}$ & Texture \\
S3 & Moderate suitable & 3 & Moderate & $\mathrm{d}$ & Drainage \\
S4 & Marginally suitable & 4 & Severe & $\mathrm{c}$ & Carbonate \\
S5 & Not suitable & 5 & Very severe & $\mathrm{s}$ & Salinity \\
& & & & $\mathrm{a}$ & Sodium saturation \\
& & & $\mathrm{g}$ & Profile development \\
\hline
\end{tabular}




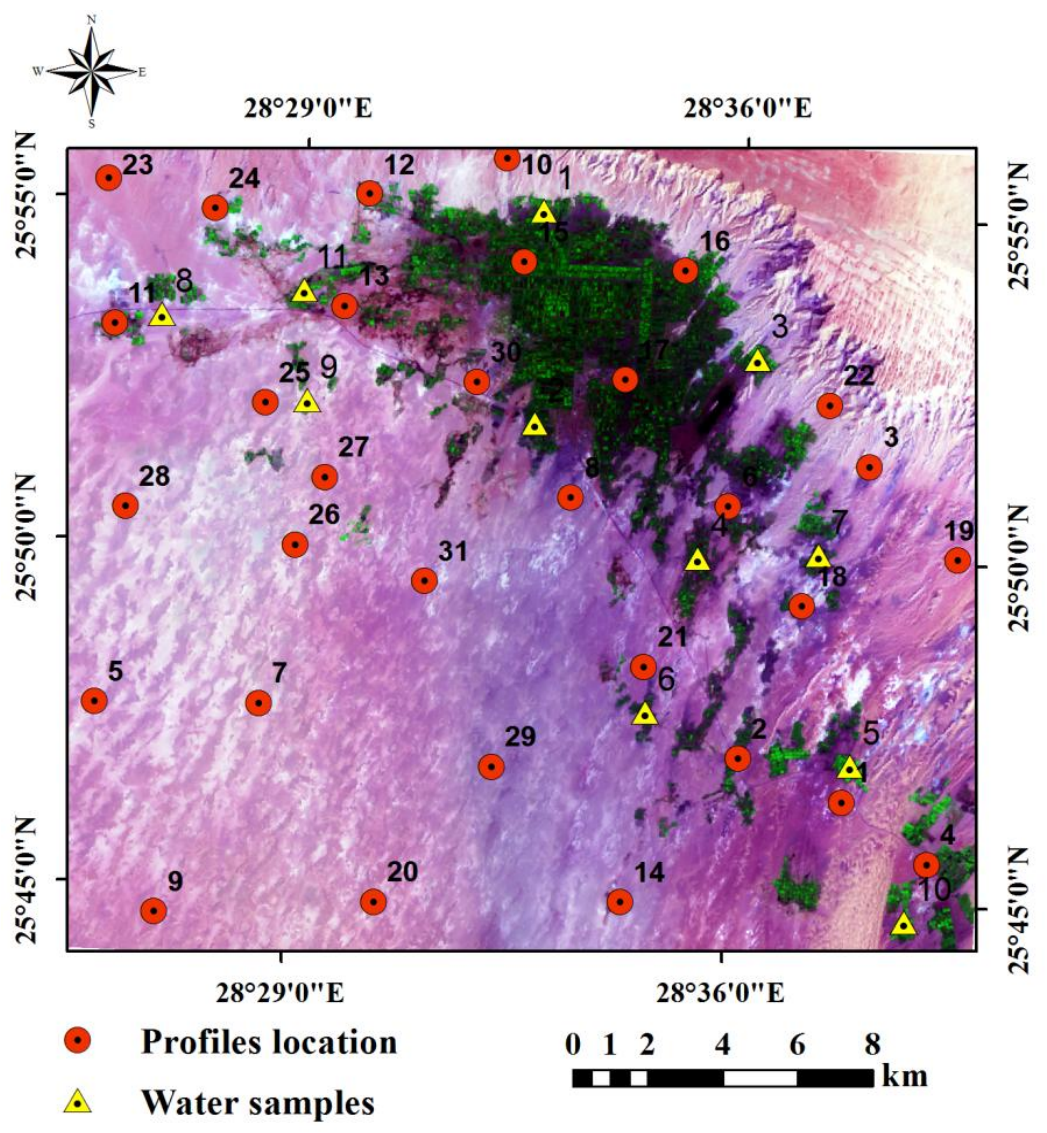

Fig. 3. Soil profiles and water samples in the studied area

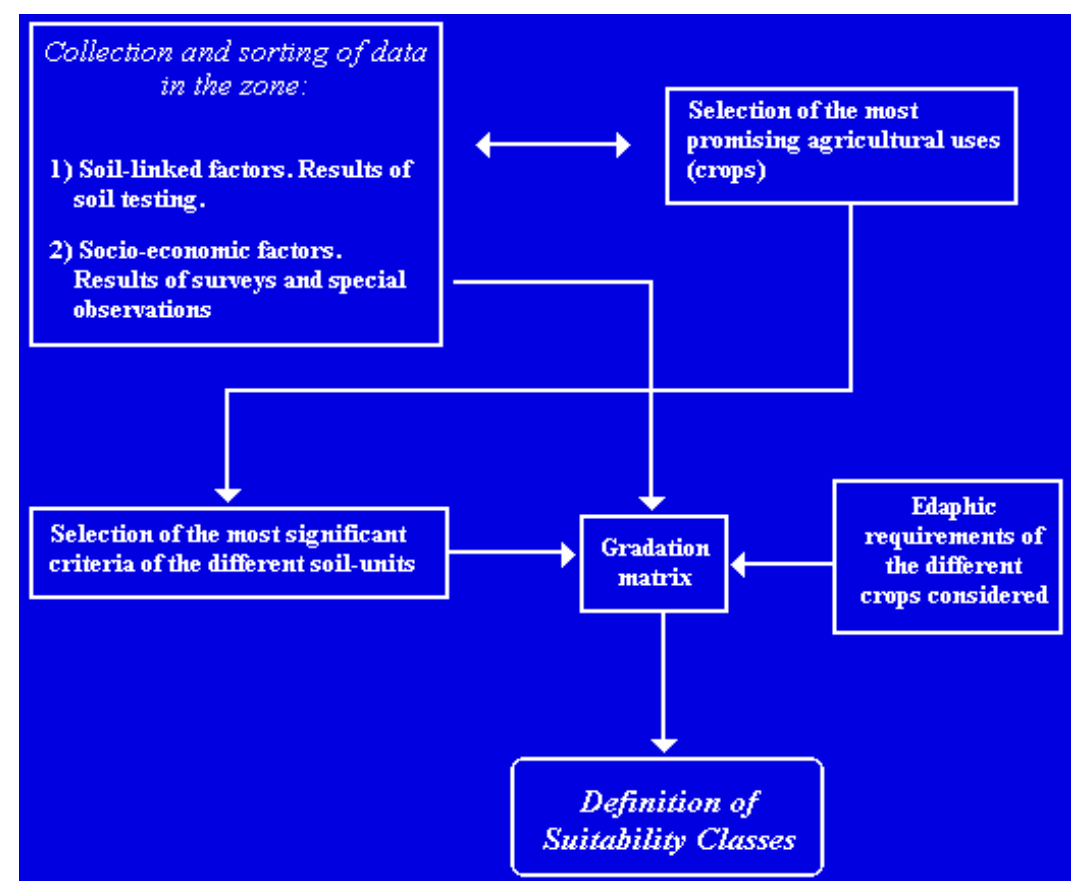

Fig. 4. Diagram showing the methodology followed in Almagra model 


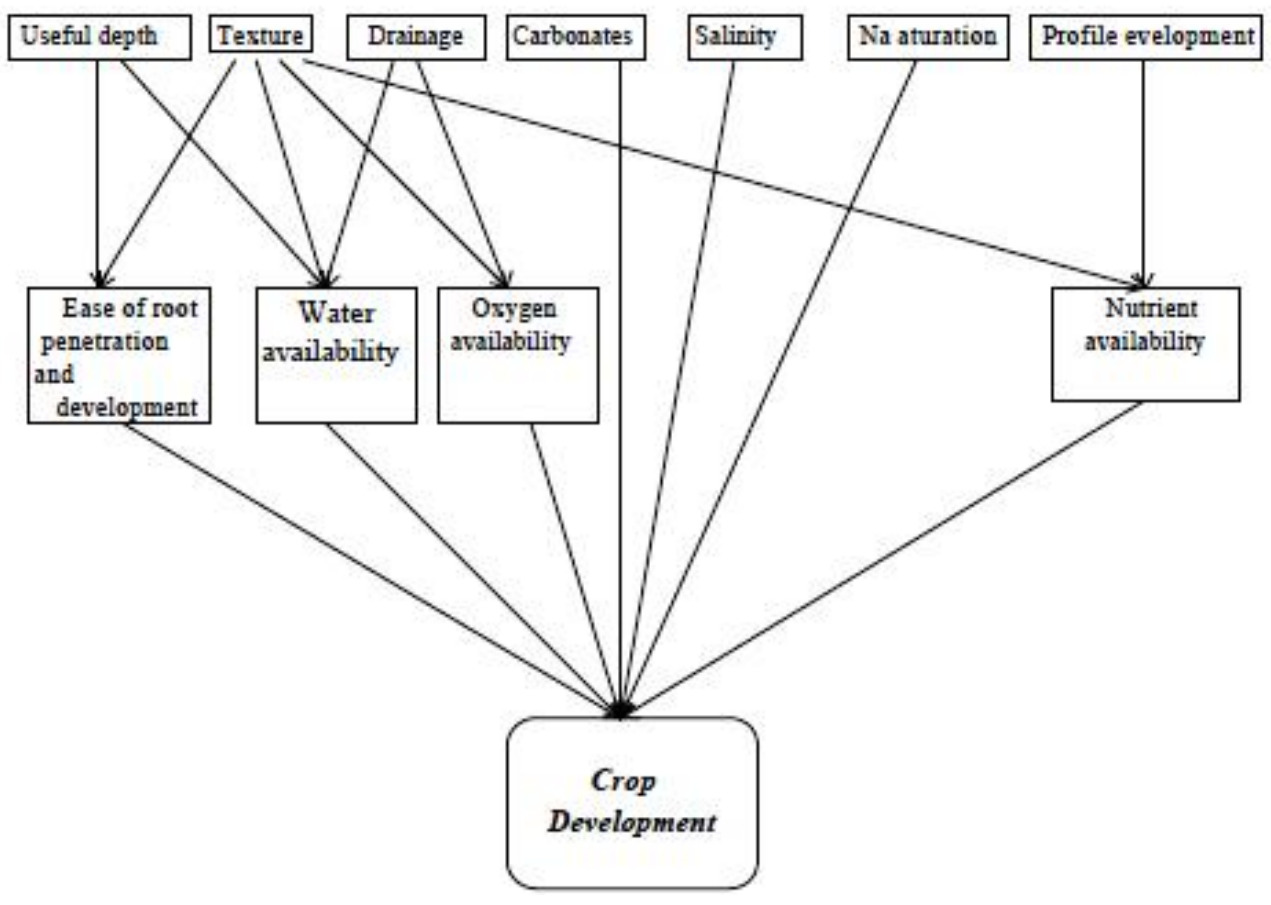

Fig. 5. Direct and indirect effects of the selected soil characteristics on crop production

\subsection{Crop Water Requirements}

Crop water requirements are commonly estimated with the FAO-56 methodology. This procedure based upon a two-step: first a reference evapotranspiration (ETo) is calculated from COPWAT 8.0 software using weather variables with the Penman-Monteith equation, then the ETo is multiplied by a tabulated cropspecific coefficient $(\mathrm{Kc})$ adapted from Allen et al. [32] to determine the water requirement (ETc) of a given crop under standard conditions [33].

\section{RESULTS AND DISCUSSION}

\subsection{Geomorphology of the Studied Area}

The landforms and physiographic soil map legend are presented in Fig. 6 and Table 2. The main landscapes in the area are plateau, pediplain, depression, and Aeolian plain. The plateau covers $46.45 \mathrm{~km}^{2}$ in the northeastern zone and represents $8.37 \%$ of the total area. It includes the landforms of summit $\left(33.13 \mathrm{~km}^{2}\right)$ and escarpment $\left(13.32 \mathrm{~km}^{2}\right)$. The pediplain occupies the smallest part, which represents $2.87 \%$ of the total area, covering $15.91 \mathrm{~km}^{2}$. The depression covers the greatest part, $60.80 \%$ of the total area, and occupies $337.62 \mathrm{~km}^{2}$ in the middle part of the area. The included landforms within this landscape are depression edge $\left(130.21 \mathrm{~km}^{2}\right)$ and depression floor $\left(207.41 \mathrm{~km}^{2}\right)$. The Aeolian plain covers $155.29 \mathrm{~km}^{2}$ and represents $27.97 \%$ of the total area. The landforms in this landscape are sand sheets (low and moderate), covering 119.28 and $36.01 \mathrm{~km}^{2}$, respectively.

\subsection{Soils of the Study Area}

\subsubsection{Soils of the pediplain}

As shown in Table 3 , the soils are gently sloping $(2.72-2.76 \%)$ and moderately deep to deep (70$110 \mathrm{~cm}$ ). Soil texture is gravelly and very gravelly sandy loam. According to Soil Survey Staff [34], the soils are slightly to moderately alkaline and slightly to strongly saline since $\mathrm{pH}$ ranged from 7.61 to 7.88 , while EC ranged from 7.22 to 23.90 $\mathrm{dS} \mathrm{m}^{-1}$. Soil organic matter varied from 0.92 to $1.25 \mathrm{~g} \mathrm{~kg}^{-1}$. Calcium carbonate and gypsum varied from 154.10 to $548.20 \mathrm{~g} \mathrm{~kg}^{-1}$ for the former and from 52.32 to $61.46 \mathrm{~g} \mathrm{~kg}^{-1}$ for the latter. CEC ranged from 7.80 to 11.60 cmolc $\mathrm{kg}^{-1}$ soil. ESP varied from 2.21 to 8.92 , indicating none-sodic soils. The main soil subgroup is Typic Torriorthents. 
Fadl and Abuzaid; IJPSS, 16(6): 1-16, 2017; Article no.IJPSS.33835

Table 2. Physiographic legend and soils of the studied area

\begin{tabular}{|c|c|c|c|c|c|c|c|}
\hline Landscape & Relief & Lithology/origin & Landform & $\begin{array}{l}\text { Area, } \\
\mathrm{km}^{2}\end{array}$ & $\begin{array}{l}\text { Area, } \\
\%\end{array}$ & Main soil & $\begin{array}{l}\text { Kind of } \\
\text { mapping unit }\end{array}$ \\
\hline \multirow[t]{2}{*}{ Plateau } & Almost flat & Limestone & Summit & 33.13 & 5.97 & Rocky area & --- \\
\hline & Rolling & & Escarpment & 13.32 & 2.40 & & \\
\hline Pediplain & $\begin{array}{l}\text { Flat to almost } \\
\text { flat }\end{array}$ & Limestone, siltstone, sandstone & Pediplain & 15.91 & 2.87 & Typic Torriorthents & Consociation \\
\hline \multirow[t]{2}{*}{ Depression } & $\begin{array}{l}\text { Gently } \\
\text { undulating }\end{array}$ & $\begin{array}{l}\text { Shale, clay stone, limestone, } \\
\text { siltstone, sandstone }\end{array}$ & Depression edge & 130.21 & 23.45 & $\begin{array}{l}\text { Typic Torriorthents } \\
\text { Typic Haplocalcids } \\
\text { Typic Haplosalids }\end{array}$ & Complex \\
\hline & Almost flat & & Depression floor & 207.41 & 37.35 & $\begin{array}{l}\text { Typic Torriorthents } \\
\text { Vertic Torriorthents }\end{array}$ & Association \\
\hline $\begin{array}{l}\text { Aeolian } \\
\text { plain }\end{array}$ & $\begin{array}{l}\text { Gently } \\
\text { undulating }\end{array}$ & Sandstone, limestone & $\begin{array}{l}\text { Low sand sheet } \\
\text { Moderate sand sheet }\end{array}$ & $\begin{array}{l}119.28 \\
36.01\end{array}$ & $\begin{array}{l}21.48 \\
6.49\end{array}$ & $\begin{array}{l}\text { Typic } \\
\text { Torripsamments }\end{array}$ & Consociation \\
\hline
\end{tabular}



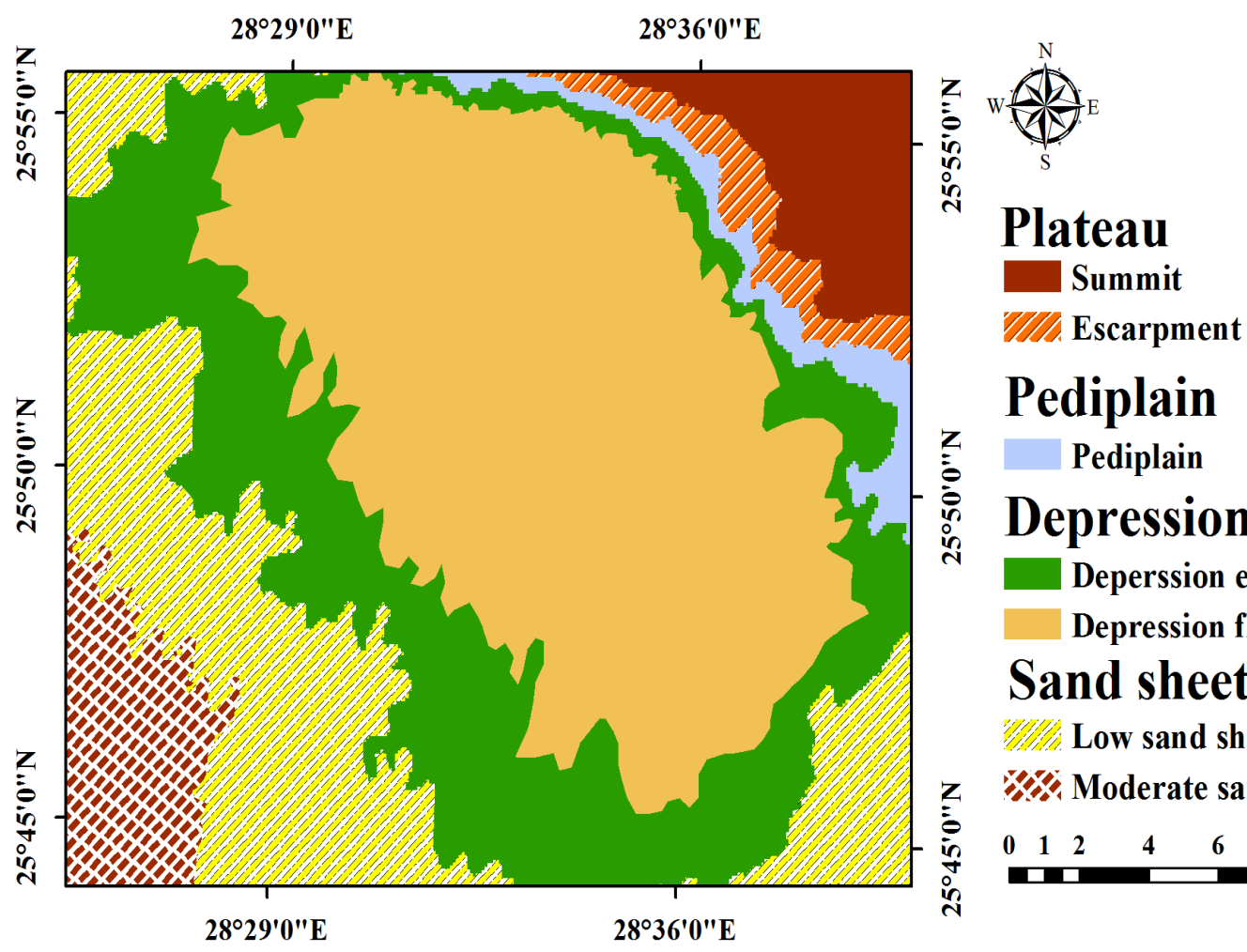

\section{Pediplain}

\section{z Pediplain \\ Depression \\ Deperssion edge \\ Depression floor \\ Sand sheets}

Low sand sheet

Moderate sand sheet

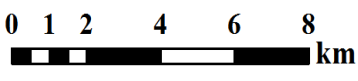

Fig. 6. Landforms of the studied area

Table 3. Main soil properties of the studied area

\begin{tabular}{llll}
\hline Soil properties & Pediplain & Depression & Sand sheet \\
\hline Slope, \% & $2.72-2.76$ & $0.31-1.89$ & $1.21-8.56$ \\
Gravel, \% & $15.11-44.89$ & $0.13-3.96$ & $0.56-11.45$ \\
Soil depth, cm & $70-110$ & $95-150$ & $90-130$ \\
Soil texture & GSL - VGSL & $\mathrm{SL}-\mathrm{C}$ & $\mathrm{S}-\mathrm{SGLS}$ \\
$\mathrm{pH}$ & $7.61-7.88$ & $7.18-7.82$ & $7.46-8.03$ \\
$\mathrm{EC}, \mathrm{dS} \mathrm{m}^{-1}$ & $7.22-23.90$ & $5.11-40.52$ & $5.67-23.53$ \\
$\mathrm{OM}, \mathrm{g} \mathrm{kg}^{-1}$ & $0.92-1.25$ & $0.59-10.75$ & $0.74-4.92$ \\
$\mathrm{CaCO}_{3}, \mathrm{~g} \mathrm{~kg}^{-1}$ & $154.10-548.20$ & $56.10-449.29$ & $106.10-604.20$ \\
$\mathrm{Gypsum}^{-1}$ & $52.32-61.46$ & $8.15-81.22$ & $21.33-36.52$ \\
$\mathrm{CEC}, \mathrm{cmolc} \mathrm{kg}^{-1}$ & $7.80-11.60$ & $12.30-54.10$ & $7.60-29.20$ \\
ESP & $2.21-8.92$ & $2.51-32.33$ & $4.10-30.41$ \\
\hline \multicolumn{1}{c}{ VG, very gravelly; G, gravelly; SG; slightly gravelly; SL, sandy loam; C, clay; S, sand; LS, loamy sand }
\end{tabular}

\subsubsection{Soils of the depression}

The soils are flat to very gently sloping and moderately deep to very deep. Slope values ranged from 0.31 to $1.89 \%$ with a soil depth of 95 to $150 \mathrm{~cm}$. Soil texture varied from sandy loam to clay. Soil $\mathrm{pH}$ varied from 7.18 to 7.82 , indicating that the soils are neutral to slightly alkaline. Soil salinity varied from slightly saline to strongly saline with EC of 5.11 to $40.52 \mathrm{dS} \mathrm{m}^{-1}$. As a result of the absence of natural vegetation and aridity, soil organic matter was low with values of 0.59 to $10.75 \mathrm{~g} \mathrm{~kg}^{-1}$. Calcium carbonate and gypsum contents varied from 56.10 to $1.12 \mathrm{~g} \mathrm{~kg}^{-1}$ and from 8.15 to $81.22 \mathrm{~g} \mathrm{~kg}^{-1}$, respectively. Cation exchange capacity (CEC) varied from 12.30 to 54.10 cmolc $\mathrm{kg}^{-1}$ soil, while exchangeable sodium percentage (ESP) 
varied from 2.51 to 32.33 . The main soil subgroups are Typic Torriorthents, Vertic Torriorthents, Typic Haplosalids and Typic Haplocalcids.

\subsubsection{Soil of the sand sheet}

The slope ranged from 1.21 to $8.56 \%$, which means that the soils are very gently sloping to sloping. The soils are moderately deep to very deep since soil depth ranged from 90 to $190 \mathrm{~cm}$. The soils are sandy to slightly gravelly loamy sand. Values of $\mathrm{pH}$ and $\mathrm{EC}$ ranged from 7.46 to 8.03 and from 5.67 to $23.53 \mathrm{dS} \mathrm{m}^{-1}$, respectively. Thus, the soils are slightly to moderately alkaline and slightly to strongly saline with organic matter of 0.74 to $4.92 \mathrm{~g} \mathrm{~kg}^{-1}$. Calcium carbonate and gypsum ranged from 106.10 to $604.20 \mathrm{~g} \mathrm{~kg}^{-1}$ for the former and from 21.33 to $36.52 \mathrm{~g} \mathrm{~kg}^{-1}$ for the latter. CEC varied from 7.60 to $29.20 \mathrm{cmolc} \mathrm{kg}^{-1}$ soil and ESP varied from 4.10 to 30.41 . The main soil subgroup is Typic Torripsamments.

\subsection{Water Quality for Irrigation}

The chemical composition of irrigation water is shown in Table 4. Results show that $\mathrm{pH}$ values ranged from 6.85 to 7.82 , indicating a normal range for irrigation $(6.5$ - 8.4).Salinity shows low values in all wells with $E C$ ranging from 0.21 to $0.31 \mathrm{dS} \mathrm{m}^{-1}$. Values of SAR varied from 0.58 to 1.12 , with negative RSC values. The results indicate that water quality is good for irrigating. Such high water quality enables crop cultivation under salinity and sodicity stress.

\subsection{Crop Water Requirements}

The crop water requirements for the selected crops are presented in Table 5 . Values of the ETo from January to December were 3.1, 3.9, $5.3,6.8,8.4,8.7,8.8,8.3,7.3,5.7,3.8$ and 2.9 $\mathrm{mm}$ day $^{-1}$. The calculated ETc values for the selected crops were as follows: maize $=816.33$ $\mathrm{mm}$, sunflower $=795.98 \mathrm{~mm}$, soy bean $=$ $1003.83 \mathrm{~mm}$, wheat $=550.78 \mathrm{~mm}$, sugar beet $=$ $865.13 \mathrm{~mm}$, cotton $=1150.83 \mathrm{~mm}$, watermelon $=$ $797.87 \mathrm{~mm}$, alfalfa $=2113.47 \mathrm{~mm}$, potato $=$ $397.37 \mathrm{~mm}$, peach $=1577.86$, citrus $=1503.92$ $\mathrm{mm}$ and olive $=1163.96 \mathrm{~mm}$.

\subsection{Land Suitability for Selected Crops}

The agricultural suitability performed by applying MicroLEIS-Almagra model for different mapping units is presented in Fig. 7 and Table 6 . Calculations were done using modal profile representing the dominant main soil in each mapping unit. Soils of depression and sand sheets are high suitable (S2), moderately suitable (S3) and marginally suitable (S4) for all selected crops, except watermelon, peach, citrus, and olive, as the soils are moderately suitable (S3), marginally suitable (S4) and not suitable (S5), respectively. On the other hand, soils of the pediplain have severe limitations, and thus they are not suitable (S5) for all the selected crops. The most recommended crop in the area is sugar beet, as $66.35 \%$ of the soils are suitable (S2).

Table 4. Chemical composition of irrigation water samples

\begin{tabular}{|c|c|c|c|c|c|}
\hline Sample & $\mathrm{pH}$ & $E C, d S ~ m^{-1}$ & TDS, $\mathrm{mg} \mathrm{L}^{-1}$ & SAR & RSC \\
\hline 1 & 7.61 & 0.21 & 122.00 & 0.58 & -0.66 \\
\hline 2 & 7.82 & 0.30 & 177.00 & 0.97 & -0.74 \\
\hline 3 & 6.95 & 0.29 & 179.00 & 0.95 & -0.81 \\
\hline 4 & 6.91 & 0.26 & 153.00 & 0.86 & -0.62 \\
\hline 5 & 6.93 & 0.25 & 147.00 & 1.12 & -0.58 \\
\hline 6 & 6.85 & 0.24 & 142.00 & 0.75 & -0.64 \\
\hline 7 & 7.73 & 0.21 & 124.00 & 0.66 & -0.51 \\
\hline 8 & 7.61 & 0.29 & 175.00 & 1.12 & -0.76 \\
\hline 9 & 7.31 & 0.25 & 150.00 & 0.95 & -0.62 \\
\hline 10 & 7.52 & 0.26 & 155.00 & 0.96 & -0.95 \\
\hline 11 & 7.11 & 0.31 & 188.00 & 1.03 & -0.75 \\
\hline
\end{tabular}

EC, electrical conductivity; TDS, total dissolved solids; SAR, sodium adsorption ratio; $R S C$, residual sodium carbonate 
Fadl and Abuzaid; IJPSS, 16(6): 1-16, 2017; Article no.IJPSS.33835

Table 5. Crop water requirements $\left(\mathrm{mm}\right.$ season $\left.{ }^{-1}\right)$ for the proposed crops in the studied area

\begin{tabular}{|c|c|c|c|c|c|c|c|c|c|}
\hline \multirow[t]{2}{*}{ Month } & \multirow{2}{*}{$\begin{array}{l}\text { ETo, } \\
\text { mm day }^{-1}\end{array}$} & \multicolumn{2}{|r|}{ Maize } & \multicolumn{2}{|r|}{ Sunflower } & \multicolumn{2}{|r|}{ Soya bean } & \multicolumn{2}{|r|}{ Wheat } \\
\hline & & Kc & $\begin{array}{l}\text { ETc, } \\
\text { mm month }^{-1}\end{array}$ & Kc & $\begin{array}{l}\text { ETc, } \\
\text { mm month }^{-1}\end{array}$ & Kc & $\begin{array}{l}\text { ETc, } \\
\text { mm month }^{-1}\end{array}$ & Kc & $\begin{array}{l}\text { ETc, } \\
\text { mm month }^{-1}\end{array}$ \\
\hline Jan & 3.10 & & & & & & & 0.93 & 89.37 \\
\hline Feb & 3.90 & & & & & & & 1.15 & 125.58 \\
\hline March & 5.30 & & & & & & & 1.15 & 188.95 \\
\hline April & 6.80 & & & & & 0.50 & 102.00 & 0.72 & 146.88 \\
\hline May & 8.40 & 0.30 & 78.12 & 0.35 & 91.14 & 0.86 & 223.94 & & \\
\hline June & 8.70 & 0.89 & 232.29 & 0.91 & 237.51 & 1.00 & 261.00 & & \\
\hline July & 8.80 & 1.10 & 300.08 & 1.10 & 300.08 & 1.00 & 272.80 & & \\
\hline August & 8.30 & 0.80 & 205.84 & 0.65 & 167.25 & 0.56 & 144.09 & & \\
\hline September & 7.30 & & & & & & & & \\
\hline October & 5.70 & & & & & & & & \\
\hline November & 3.80 & & & & & & & & \\
\hline December & 2.90 & & & & & & & & \\
\hline \multicolumn{2}{|c|}{ Total ETc, mm season ${ }^{-1}$} & \multicolumn{2}{|r|}{816.33} & \multirow{2}{*}{\multicolumn{2}{|c|}{$\begin{array}{l}795.98 \\
\text { Cotton }\end{array}$}} & \multirow{2}{*}{\multicolumn{2}{|c|}{$\begin{array}{c}1003.83 \\
\text { Watermelon }\end{array}$}} & \multirow{2}{*}{\multicolumn{2}{|c|}{$\begin{array}{c}550.78 \\
\text { Alfalfa }\end{array}$}} \\
\hline \multirow[t]{2}{*}{ Month } & \multirow{2}{*}{$\begin{array}{l}\text { ETo, } \\
\text { mm day }^{-1}\end{array}$} & \multicolumn{2}{|r|}{ Sugar beet } & & & & & & \\
\hline & & Kc & $\begin{array}{l}\text { ETc, } \\
\text { mm month }^{-1}\end{array}$ & $\mathrm{Kc}$ & $\begin{array}{l}\text { ETc, } \\
\text { mm month }^{-1}\end{array}$ & \multicolumn{2}{|c|}{$\begin{array}{l}\text { Watermelon } \\
\text { ETc, } \\
\text { mm month }{ }^{-1}\end{array}$} & Kc & $\begin{array}{l}\text { ETc, } \\
\text { mm month }\end{array}$ \\
\hline Jan & 3.10 & 1.05 & 100.91 & & & & & 0.95 & 91.30 \\
\hline Feb & 3.90 & 1.20 & 131.04 & & & & & 0.95 & 103.74 \\
\hline March & 5.30 & 1.20 & 197.16 & 0.35 & 57.51 & & & 0.95 & 156.09 \\
\hline April & 6.80 & 1.18 & 240.72 & 0.40 & 81.60 & 0.55 & 112.20 & 0.95 & 193.80 \\
\hline May & 8.40 & 0.75 & 195.30 & 0.83 & 216.13 & 0.78 & 203.11 & 0.95 & 247.38 \\
\hline June & 8.70 & & & 1.10 & 287.10 & 0.95 & 247.95 & 0.95 & 247.95 \\
\hline July & 8.80 & & & 1.10 & 300.08 & 0.86 & 234.61 & 0.95 & 259.16 \\
\hline August & 8.30 & & & 0.81 & 208.41 & & & 0.95 & 244.44 \\
\hline September & 7.30 & & & & & & & 0.95 & 208.05 \\
\hline October & 5.70 & & & & & & & 0.95 & 167.87 \\
\hline November & 3.80 & & & & & & & 0.95 & 108.30 \\
\hline December & 2.90 & & & & & & & 0.95 & 85.41 \\
\hline \multicolumn{2}{|c|}{ Total ETc, $\mathrm{mm}$ season $^{-1}$} & & 865.13 & & 1150.83 & & 797.87 & & 2113.47 \\
\hline
\end{tabular}


Fadl and Abuzaid; IJPSS, 16(6): 1-16, 2017; Article no.IJPSS.33835

\begin{tabular}{|c|c|c|c|c|c|c|c|c|c|}
\hline \multirow[t]{2}{*}{ Month } & \multirow{2}{*}{$\begin{array}{l}\text { ETo, } \\
\text { mm day }^{-1}\end{array}$} & \multicolumn{2}{|r|}{ Potato } & \multicolumn{2}{|r|}{ Peach } & \multicolumn{2}{|r|}{ Citrus } & \multicolumn{2}{|r|}{ Olive } \\
\hline & & Kc & $\begin{array}{l}\text { ETc, } \\
\text { mm month }^{-1}\end{array}$ & Kc & $\begin{array}{l}\text { ETc, } \\
\text { mm month }^{-1}\end{array}$ & Kc & $\begin{array}{l}\text { ETc, } \\
\text { mm month }^{-1}\end{array}$ & Kc & $\begin{array}{l}\text { ETc, } \\
\text { mm month }\end{array}$ \\
\hline Jan & 3.10 & 0.97 & 93.22 & & & 0.75 & 72.08 & 0.50 & 48.05 \\
\hline Feb & 3.90 & & & & & 0.75 & 81.90 & 0.50 & 54.60 \\
\hline March & 5.30 & & & 0.55 & 90.37 & 0.73 & 119.94 & 0.65 & 106.80 \\
\hline April & 6.80 & & & 0.68 & 138.72 & 0.70 & 142.80 & 0.61 & 124.44 \\
\hline May & 8.40 & & & 0.83 & 216.13 & 0.67 & 174.47 & 0.55 & 143.22 \\
\hline June & 8.70 & & & 0.90 & 234.90 & 0.65 & 169.65 & 0.48 & 125.28 \\
\hline July & 8.80 & & & 0.90 & 245.52 & 0.65 & 177.32 & 0.45 & 122.76 \\
\hline August & 8.30 & & & 0.90 & 231.57 & 0.65 & 167.25 & 0.45 & 115.79 \\
\hline September & 7.30 & & & 0.90 & 197.10 & 0.65 & 142.35 & 0.49 & 107.31 \\
\hline October & 5.70 & 0.60 & 106.02 & 0.82 & 144.89 & 0.66 & 116.62 & 0.56 & 98.95 \\
\hline November & 3.80 & 0.91 & 103.74 & 0.69 & 78.66 & 0.68 & 77.52 & 0.63 & 71.82 \\
\hline December & 2.90 & 1.05 & 94.40 & & & 0.69 & 62.03 & 0.50 & 44.95 \\
\hline \multicolumn{2}{|c|}{ Total ETc, mm season ${ }^{-1}$} & & 397.37 & & 1577.86 & & 1503.92 & & 1163.96 \\
\hline
\end{tabular}


The limiting factors are salinity, followed by lime content, sodium saturation, and soil depth. Salinity and alkalinity are difficult to be reclaimed due to salt enriched parent material such as shale/limestone [35,36]. Also, high evaporation rate results in salt accumulation at the soil surface [37]. Finally, the impermeable layers under the shallow soil profiles prevent water
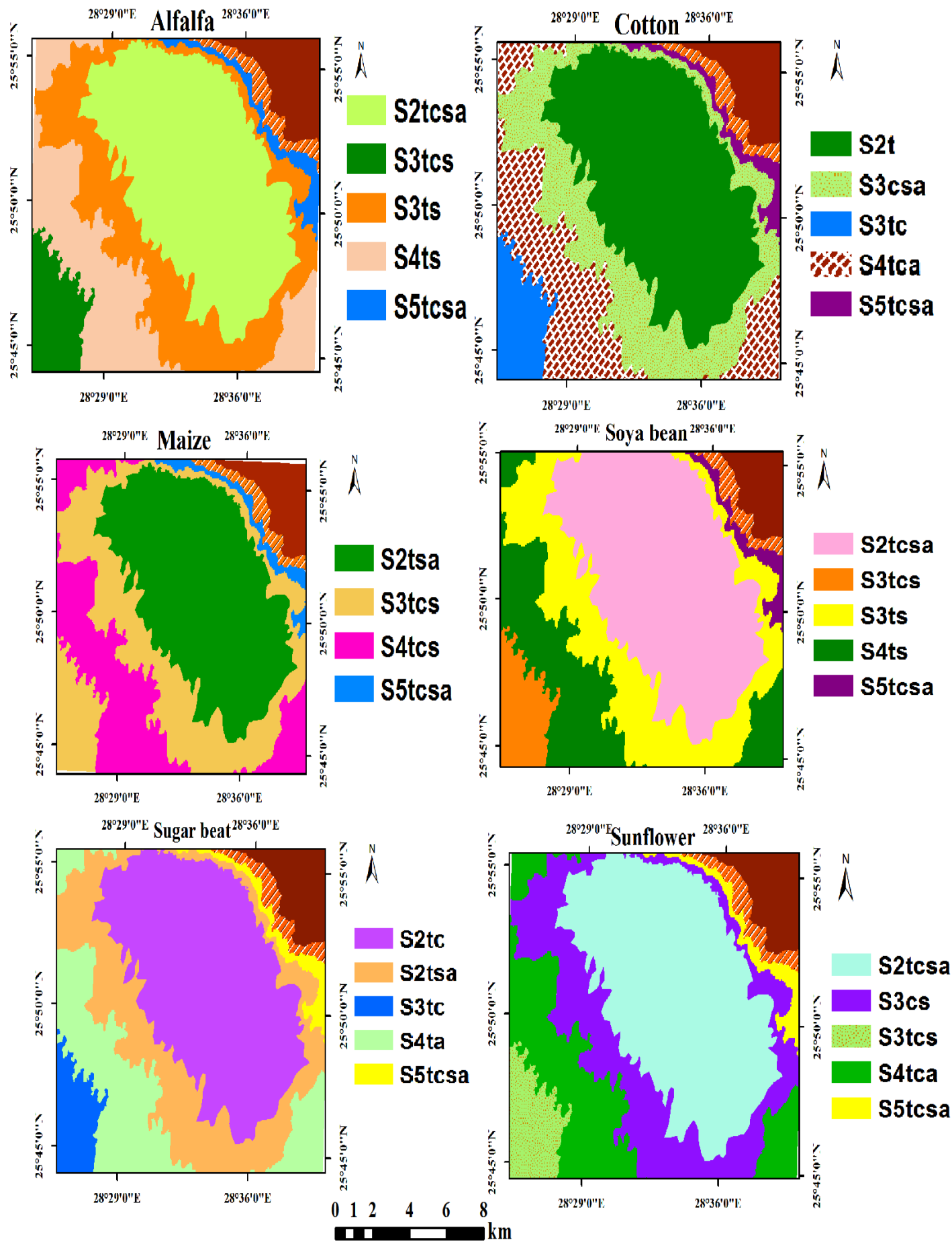

Summit

Escarpment 
Fig. 7. Cont.
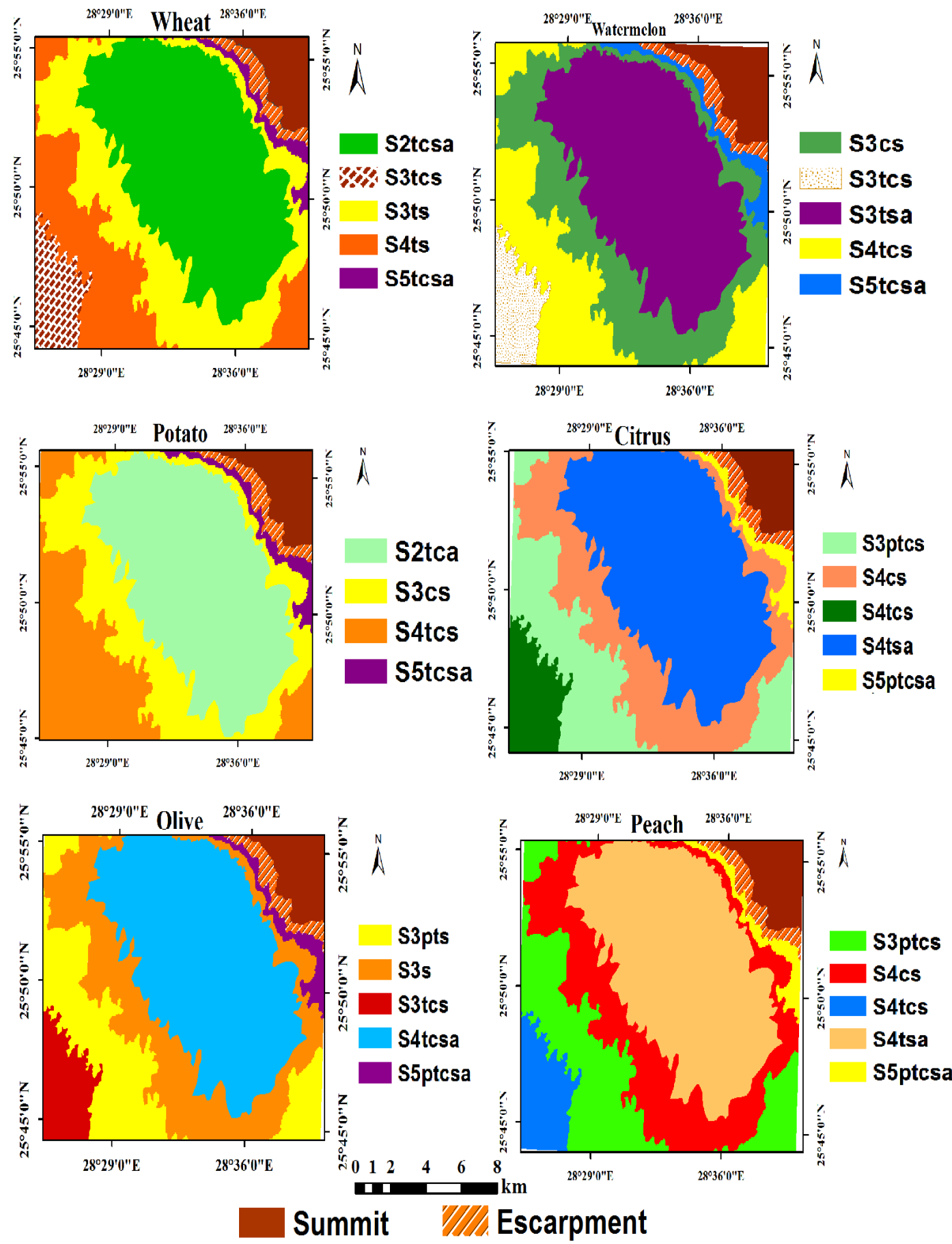

Fig. 7. Land suitability for the selected crops in the study area

(S2, high suitable; S3, moderate suitable; S4, marginal suitable; S5, unsuitable; Letters follow the Arabic number are the limiting factors; depth $(p)$, texture $(t)$, carbonate $(c)$, salinity $(s)$ and sodium saturation $(a)$

percolation and lead to high water table levels [38]. Soil depth and lime content are permanent limiting factors which could not be improved. Soil depth is very apparent limiting factor in the 
Table 6. Relative extent of land suitability in the studied area

\begin{tabular}{|c|c|c|c|c|c|c|c|c|}
\hline \multirow[t]{2}{*}{ Crop } & \multicolumn{2}{|c|}{ S2 } & \multicolumn{2}{|c|}{ S3 } & \multicolumn{2}{|c|}{ S4 } & \multicolumn{2}{|c|}{ S5 } \\
\hline & $\begin{array}{l}\text { Area, } \\
\text { km }^{2}\end{array}$ & $\begin{array}{l}\text { Area, } \\
\%\end{array}$ & $\begin{array}{l}\text { Area, } \\
\text { km }^{2}\end{array}$ & $\begin{array}{l}\text { Area, } \\
\%\end{array}$ & $\begin{array}{l}\text { Area, } \\
\text { km }^{2}\end{array}$ & $\begin{array}{l}\text { Area, } \\
\%\end{array}$ & $\begin{array}{l}\text { Area, } \\
\mathrm{km}^{2}\end{array}$ & $\begin{array}{l}\text { Area, } \\
\%\end{array}$ \\
\hline Wheat & 207.41 & 40.76 & 166.22 & 32.67 & 119.28 & 23.44 & 15.91 & 3.13 \\
\hline Maize & 207.41 & 40.76 & 166.22 & 32.67 & 119.28 & 23.44 & 15.91 & 3.13 \\
\hline Watermelon & & - & 373.63 & 73.43 & 119.28 & 23.44 & 15.91 & 3.13 \\
\hline Potato & 207.41 & 40.76 & 130.21 & 25.59 & 155.29 & 30.52 & 15.91 & 3.13 \\
\hline Soya bean & 207.41 & 40.76 & 166.22 & 32.67 & 119.28 & 23.44 & 15.91 & 3.13 \\
\hline Cotton & 207.41 & 40.76 & 166.22 & 32.67 & 119.28 & 23.44 & 15.91 & 3.13 \\
\hline Sunflower & 207.41 & 40.76 & 166.22 & 32.67 & 119.28 & 23.44 & 15.91 & 3.13 \\
\hline Sugar beet & 337.62 & 66.35 & 36.01 & 7.08 & 119.28 & 23.44 & 15.91 & 3.13 \\
\hline Alfalfa & 207.41 & 40.76 & 166.22 & 32.67 & 119.28 & 23.44 & 15.91 & 3.13 \\
\hline Peach & & 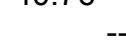 & 119.28 & 23.44 & 373.63 & 73.43 & 15.91 & 3.13 \\
\hline Citrus & & $\ldots$ & 119.28 & 23.44 & 373.63 & 73.43 & 15.91 & 3.13 \\
\hline Olive & & - & 285.50 & 56.11 & 207.41 & 40.76 & 15.91 & 3.13 \\
\hline
\end{tabular}

pediplain unit. The importance of soil depth goes beyond the ease of root penetration and development [39]. Lime affects soil water relations and the availability of plant nutrients [40].

\section{CONCLUSION}

Assessment of land suitability for different crops helps in planning sustainable agriculture programs. An approach integrating remote sensing, GIS and the Micro LIES software (Almagra model) was undertaken in this study to assess the land performance of $555.27 \mathrm{~km}^{2}$ (55527 ha) west of Dakhla oasis. About $97 \%$ of the studied soils are suitable for all the selected crops, while the remaining area (about $3 \%$ ) is unsuitable. The most predominant limiting factors are salinity, lime content, sodicity and soil depth. The area is characterized by high water quality, giving it a priority in agricultural expansion projects.

\section{ACKNOWLEDGEMENTS}

The authors express their deep thanks to Prof. Dr. Ali Ahmed Abd El-Salam, Soil and Water Department, Faculty of Agriculture, Benha University and Prof. Dr. Mahmoud Khairy Mohamed Soil, Water and Environment Research Institute (SWERI), Agricultural Research Center (ARC), Egypt for their valuable comments.

\section{COMPETING INTERESTS}

Authors have declared that no competing interests exist.

\section{REFERENCES}

1. Zidan MS, Dawoud MA. Agriculture use of marginal water in Egypt: Opportunities and challenges. In: Shahid SA, Abdelfattah MA, Taha FK, Editors. Developments in soil salinity assessment and reclamation: Innovative thinking and use of marginal soil and water resources in irrigated agriculture. Springer Netherlands: Dordrecht; 2013.

2. Kamel M, Abu El Ella ESM. Integration of remote sensing \& GIS to manage the sustainable development in the Nile Valley Desert fringes of Assiut-Sohag Governorates, Upper Egypt. J. Indian Soc. Remot. 2016;44(5):759-774.

3. El-Ramady HR, El-Marsafawy SM, Lewis $\mathrm{LN}$. Sustainable agriculture and climate changes in Egypt. In: Lichtfouse E, Editor. Sustainable agriculture reviews: Springer Netherlands: Dordrecht. 2013;12.

4. Shalaby A. Moghanm FS. Assessment of urban sprawl on agricultural soil of northern Nile Delta of Egypt using RS and GIS. Chinese Geogr. Sci. 2015;25(3):274282.

5. Adriansen HK. Land reclamation in Egypt: A study of life in the new lands. Geoforum. 2009;40(4):664-674.

6. El Kashouty M, Aziz AA, Soliman M, Mesbah H. Hydrogeophysical investigation of groundwater potential in the El Bawiti, Northern Bahariya Oasis, Western Desert, Egypt. Arab. J. Geosci. 2012;5(5):953-970.

7. Abdel Kawy WA. Darwish KM. Assessment of optimum land use and water requirements for agricultural purpose in 
some soils South Paris Oasis, Western Desert, Egypt. Arab. J. Geosci. 2014; 7(10):4043-4058.

8. Khan SD, Fathy MS, Abdelazeem M. Remote sensing and geophysical investigations of Moghra Lake in the Qattara depression, Western Desert, Egypt. Geomorphology. 2014;207:10-22.

9. Elsheikh AE. Mitigation of groundwater level deterioration of the Nubian Sandstone aquifer in Farafra Oasis, Western Desert, Egypt. Environ. Earth Sci. 2015;74(3):2351-2367.

10. Kato H, Kimura R, Elbeih SF, Iwasaki E, Zaghloul EA. Land use change and crop rotation analysis of a government well district in Rashda village - Dakhla Oasis, Egypt based on satellite data. Egypt. J. Rem. Sens. Space Sci. 2012;15(2):185195.

11. Senosy MM, Youssef MM, Abdel Zaher M. Sedimentary cover in the South Western desert of Egypt as deduced from Bouguer gravity and drill-hole data. J. Afr. Earth Sci. 2013;82:1-14.

12. Abdel Kawy WAM, Abou El-Magd IH. Use of satellite data and GIS for assessing the agricultural potentiality of the soils South Farafra Oasis, Western Desert, Egypt. Arab. J. Geosci. 2013;6(7):22992311.

13. Hamzeh $\mathrm{S}$, et al. Feature selection as a time and cost-saving approach for land suitability classification: Case study of Shavur plain, Iran. Agriculture-Basel. 2016; 6(4).

14. Albaji M. Alboshokeh A. Assessing agricultural land suitability in the Fakkeh region, Iran. Outlook Agric. 2017;46(1):5765.

15. Jiao $S$, Zhang $X L, X u ~ Y . A$ review of Chinese land suitability assessment from the rainfall-waterlogging perspective: Evidence from the Su Yu Yuan area. J. Clean. Prod. 2017;144:100-106.

16. Bos MG. Why would we use a GIS database and remote sensing in irrigation management? In: van Dijk, A. and Bos, MG, Editors. GIS and remote sensing techniques in land- and watermanagement. Springer Netherlands: Dordrecht; 2001.

17. Singh RB, Kumar D. Remote sensing and GIS for land use/cover mapping and integrated land management: Case from the middle Ganga plain. Front. Earth Sci. 2012;6(2):167-176.
18. Maddahi Z, Jalalian A, Zarkesh MMK, Honarjo N. Land suitability analysis for rice cultivation using a GIS-based fuzzy multicriteria decision making approach: Central part of Amol District, Iran. Soil Water Res. 2017;12(1):29-38.

19. Brookes IA. Spatially variable sedimentary responses to orbitally driven pluvial climate during marine oxygen isotope stage 5.1, Dakhla Oasis region, Egypt. Quaternary Res. 2010;74(2):252-264.

20. EMA. The normals for Dakhla station, (1960 - 2010). Egyptian Meteorological Authority (EMA). Ministry of Civil Aviation, Cairo, Egypt; 2011.

21. Soil Survey Staff. Keys to soil taxonomy. $12^{\text {th }}$ Ed. Washington, DC: Department of Agriculture, Natural Resources Conservation Service; 2014.

22. ITT. ITT corporation ENVI 5.1 Software, 1133 Westchester Avenue, White Plains, New York, USA; 2014.

23. Lillesand T, Kiefer RW, Chipman J. Remote sensing and image interpretation. $7^{\text {th }}$ ed. USA: John Wiley \& Sons; 2015.

24. Ranchin T, Aiazzi B, Alparone L, Baronti S, Wald L. Image fusion-the ARSIS concept and some successful implementation schemes. ISPRS J. Photogramm. Remote Sens. 2003;58(1):4-18.

25. Dobos E, Norman B, Worstell B. The use of DEM and satellite data for regional scale soil databases. Agrokémia és Talajtan. 2002;51(1-2):263-272.

26. Zinck JA, Valenzuela CR. Soil geographic database: Structure and application examples. ITC J. 1990;3:270-294.

27. ESRI. Arc map version 10.2. user manual. ESRI, 380 New York Street, Redlands, California, USA; 2014.

28. FAO. Guidelines for soil description. $4^{\text {th }} \mathrm{Ed}$. Rome, Italy, FAO; 2006.

29. FAO. Soil survey field and laboratory methods manual. Soil Survey Investigations Report. Rome, Italy: FAO. 2009;51(1.0)

30. FAO. Water quality for agriculture: FAO Irrigation and Drainage Paper 29. Revision. 1. Rome, Italy: FAO. 1994;1130.

31. Rosa D. Agro-ecological land evaluation for sustainable rural development (in Spanish). Mundi-Prensa Press, Madrid., Spain; 2008.

32. Allen RG, Pereira LS, Raes D, Smith M. Crop evapotranspiration-guidelines for computing crop water requirements-FAO 
Irrigation and drainage paper 56. FAO, Rome. 1998;300(9):D05109.

33. Lhomme JP, Boudhina N, Masmoudi MM, Chehbouni A. Estimation of crop water requirements: Extending the one-step approach to dual crop coefficients. Hydrol. Earth Syst. Sc. 2015;19(7):32873299.

34. Soil survey staff. Soil survey manual. Soil Conservation Service. U.S. Department of Agriculture Handbook. 1993;18.

35. Adelsberger KA, Smith JR. Paleolandscape and paleoenvironmental interpretation of spring-deposited sediments in Dakhleh Oasis, Western Desert of Egypt. CATENA. 2010;83(1):722.

36. El-Desoky H, Khalil A, Farouk S, Fahmy W. Dakhla-Kharga iron-rich paleosols, Western Desert, Egypt: Geology, geochemistry, and mineralization. Arab J. Geosci. 2017;10(4):74.
37. Hereher ME, Ismael $\mathrm{H}$. The application of remote sensing data to diagnose soil degradation in the Dakhla depressionWestern Desert, Egypt. Geocarto Int. 2016;31(5):527-543.

38. Aldabaa A, et al. Land suitability classification of a desert area in Egypt for some crops using microleis program. Am Eurasian J. Agric. Environ. Sci. 2010;8(1): 80-94.

39. De la Rosa D, Mayol F, Diaz-Pereira E, Fernandez M, De la Rosa D. A land evaluation decision support system (MicroLEIS DSS) for agricultural soil protection: With special reference to the Mediterranean region. Environ. Model. Softw. 2004;19(10):929-942.

40. Aboukila EF, Nassar IN, Rashad M, Hafez, $\mathrm{M}$, Norton JB. Reclamation of calcareous soil and improvement of squash growth using brewers' spent grain and compost. J. Saudi Soc. Agric. Sci. (In Press); 2016.

(c) 2017 Fadl and Abuzaid; This is an Open Access article distributed under the terms of the Creative Commons Attribution License (http://creativecommons.org/licenses/by/4.0), which permits unrestricted use, distribution, and reproduction in any medium, provided the original work is properly cited.

Peer-review history:

The peer review history for this paper can be accessed here: http://sciencedomain.org/review-history/19577 